\title{
ANALYSIS OF THE THERMOHALINE STRUCTURE IN THE ACTIVE LAYER OF THE MARINE ENVIRONMENT ACCORDING TO THE CALCULATED HYDROPHYSICAL CHARACTERISTICS BASED ON REMOTE MEASUREMENTS (ON THE EXAMPLE OF THE BLACK SEA)
}

\author{
АНАЛІЗ ТЕРМОХАЛІННОЇ СТРУКТУРИ \\ В ДІЯЛЬНОМУ ШАРІ МОРСЬКОГО СЕРЕДОВИЩА \\ ЗА РОЗРАХОВАНИМИ ГІДРОФІЗИЧНИМИ \\ ХАРАКТЕРИСТИКАМИ НА ОСНОВІ ДИСТАНЦІЙНИХ \\ ВИМІРЮВАНЬ (НА ПРИКЛАДІ ЧОРНОГО МОРЯ)
}

\section{Andrii Sryberko ${ }^{1}$}

DOI: https://doi.org/10.30525/978-9934-26-077-3-6

Abstract. Today, one of the priority scientific directions in marine sciences is the study of the spatial distribution of hydrophysical characteristics in the marine environment by remote measurements methods. To studying the spatio-temporal variability of water temperature and salinity in the active layer of the marine environment, it is necessary to use the data of their vertical and spatial distribution. Today there does not exist an easy way to get a in situ data for the analysis of the thermohaline structure in the marine environment. Indirect definitions of the vertical and spatial distribution of water temperature and salinity through the development of various methods for the calculation of thermohaline characteristics are used to date. Main purpose of this work is to study the thermohaline structure in the active layer of the Black Sea according to the calculated hydrophysical characteristics based on satellite and hydroacoustic data. The study of the vertical distribution of water temperature and salinity in the Black Sea was carried out in the deep-water part sea at standard levels $(0,10,20,25,30,50$ meters $)$ in the spring-autumn period. This area of research is represented by the highest number of measurements and is included in the Main Black Sea

\footnotetext{
${ }^{1}$ Research Fellow,

State Institute "Hydroacoustic Branch of Institute of Geophysics

by S.I. Subbotin name of the National Academy of Sciences of Ukraine", Ukraine

(C) Andrii Sryberko
} 
current zone. The calculations of thermohaline characteristics in the marine environment are based on the original methods of calculating the vertical distribution of water temperature, sound speed and salinity of water by satellite and hydroacoustic data. These methods were developed in the State Institute "Hydroacoustic Branch of Institute of Geophysics by S.I. Subbotin name of the National Academy of Sciences of Ukraine". Mathematical and physical-statistical methods of calculation were used in the developed methods. For the efficiency of calculations an Automated Program Complex (APC) for calculating the vertical distribution of temperature and salinity fields in the marine environment by satellite and hydroacoustic data has been developed and tested on the example of the Black Sea. The initial data for the calculations using the APC are only daily satellite data of the sea surface temperature. Based on the results of calculations of the APC, maps of the vertical distribution of temperature and salinity of water on zonal and meridional sections in the Black Sea in the period of spring autumn 2018 were developed. Analysis of the results of calculations of the vertical distribution of thermohaline characteristics made it possible to identify the main features in these distributions. The features of the spatialtemporal distribution of thermohaline parameters have been analysed. The confirmation of the state of the thermohaline regime inherent in the Black Sea in the warm season was obtained. The results of calculations of the vertical distribution of thermohaline characteristics in the Black Sea deep-water area on the basis of satellite and hydroacoustic data using the developed methods showed the possibility and expediency of their application in the layer 0-50 meters in the period May-October for a detailed analysis of the state of the thermohaline structure. The developed methods and principles of building an the APC for calculation of vertical distribution of temperature and salinity fields of water according to satellite and hydroacoustic data can be applied for analysis and monitoring of others water area of the World Ocean taking into account their hydrological conditions.

\section{1. Ветуп}

Одним з найбільш пріоритетних напрямків в науках про Землю в останні десятиріччя є дослідження змін клімату нашої планети, значна роль в яких належить океану, як невід'ємної частини глобальної кліматичної системи. Для держави, що має вихід до Чорноморського узбе- 
режжя, важливо мати науково обгрунтовані уявлення про регіональні особливості океанологічних процесів і передбачати потенційні природні зміни, що впливають на функціонування морегосподарського комплексу та стан морської екосистеми.

Сучасний етап вивчення чорноморського басейну, 3 середини 1990-х років по теперішній час, визначається різким зниженням числа систематичних експедиційних досліджень відкритого моря, що обумовлено, передусім, економічними проблемами причорноморських держав, виходом 3 ладу та втратою практично усього великотоннажного науково-дослідного флоту. Основні зусилля вчених різних відомств спрямовані на аналіз та осмислення усієї сукупності інформації, отриманої на попередніх етапах, 3 метою виявлення довгоперіодних змін в екосистемах морів або їх регіонів. Крім того, наявна інформація, яка організована у вигляді сучасних баз даних та інформаційних систем, використовується для вивчення особливостей різних процесів в морських екосистемах [1, с. 10-11].

За останні двадцять років стався значний прогрес в розумінні основних фізичних та біогеохімічних процесів в Чорному морі [2; 3; 4] завдяки проведенню сучасних науково-дослідних програм. В області морських наук та технологій виник й продовжує розвиватися новий напрямок - оперативна океанографія, що спирається на широке використання інформації, отриманої за допомогою спостережень супутникових систем [5, с. 7]. Останнім часом для океанологічних досліджень використовуються комбіновані, контактні й дистанційні, методи спостережень гідрометеорологічних характеристик. На сьогодні існує велика проблема отримання контактних даних вертикального розподілу гідрофізичних характеристик Чорного моря. У випадку відсутності цих даних, використовуються розрахункові, прогностичні (змодельовані) їх значення. Тому, найчастіше доводиться прибігати до непрямих визначень вертикального та просторового розподілу цих характеристик шляхом розробок різних методик та методів розрахунку їх розподілу [6; 7; 8].

При сучасному рівні розвитку технологій дослідження та контролю стану Землі дистанційні методи спостережень виходять на передній план, оскільки дозволяють миттєво отримувати дані спостережень, проводити моніторинг великих території з дуже високою розв'язною здатністю та відстежувати динаміку процесів, що відбуваються на земній поверхні [9, с. 3]. 
Проблеми дистанційного отримання інформації про явища та процеси, що відбуваються в усій товщі морського середовища, усе більш привертають увагу дослідників й фахівців різного профілю, оскільки їх рішення дозволяє контролювати характеристики величезних водних просторів, отримувати їх інтегральні оцінки та скорочувати витрати на проведення досліджень. Традиційні методи дослідження океану з використанням науково-дослідних судів та автономних буїв не можуть охопити постійними вимірами акваторію усього океану та навіть окремих його частин, тому не дають повної картини їх просторово-часової мінливості. Для дослідження відповідної реакції моря на кліматичні зміни й антропогенну дію потрібний постійний контроль за станом морської поверхні, мінливістю верхнього перемішаного шару, вертикальною структурою та динамікою вод в діяльному шарі вод, процесами в шельфовій зоні й т.д. Стратегія комплексного використання дистанційних спостережень (супутникових та акустичних) повинна забезпечувати довготривалий й безперервний збір та системну інтеграцію даних, які отримуються різними методами за допомогою сучасних технічних засобів, що дозволить грунтуватися на них в імітаційному моделюванні [9, с. 116].

В цілому на сьогодні можна констатувати, що розрахунки просторового розподілу гідрофізичних характеристик у Світовому океані, і зокрема в Чорному морі на основі дистанційних методів вимірів $\epsilon$ актуальною задачею, вирішення якої, дає оперативну можливість відновлювати просторовий розподіл гідрофізичних характеристик як локально, так і по цілим акваторіям морів в науково-дослідницьких та прикладних цілях в області гідрографії, гідроакустиці, океанології, екології моря, судноплавстві та ін. Для цього розробляються різноманітні методи й методики $[2 ; 6 ; 7 ; 8]$.

Мета досліджень полягала у проведенні аналізу термохалінної структури в діяльному шарі морського середовища за розрахованими гідрофізичними характеристиками на основі супутникових та гідроакустичних даних. Для чого на прикладі Чорного моря були вирішені наступні задачі:

- розрахунок вертикального розподілу температури води на основі супутникової інформації за методикою [6];

- розрахунок вертикального розподілу швидкості звуку на основі супутникової інформації за методикою [7]; 
- розрахунок вертикального розподілу солоності води за супутниковими та гідроакустичними даними за методикою [8].

Аналіз термохалінної структури в діяльному шарі Чорного моря проводився на основі оригінальних методик розрахунків вертикального розподілу температури води, швидкості звуку і солоності води за супутниковими і гідроакустичними даними $[6 ; 7 ; 8]$. Ці методики розроблені в Державній установі «Відділення гідроакустики Інституту геофізики імені С.I. Суботіна НАН України».

\section{2. Методи розрахунків гідрофізичних характеристик на основі дистанційних вимірювань}

Дослідження вертикального розподілу гідрофізичних характеристик за супутниковими та гідроакустичними даними в Чорному морі проводилися в глибоководній частині моря в період весна - осінь 2018 року. Розрахунки вертикального розподілу полів термохалінних характеристик в діяльному шарі Чорного моря доцільно представити за трьома основними етапами [8, с. 15].

Перший eman. Розрахунки вертикального розподілу температури води в Чорному морі на основі супутникової інформації за методикою [6] мають наступну послідовність:

1. Знаходження статистичних залежностей між значеннями температури води на сусідніх горизонтах в Чорному морі за усередненими даними температури води та побудова рівнянь регресії.

2. Розрахунок поправок на температуру на глибинах 10, 20, 25, 50 метрів.

3. Установка критерію для розрахунку вертикального розподілу температури води $( \pm \Delta \mathrm{T})$.

Другий eman. Розрахунки швидкості звуку в Чорному морі за супутниковими даними проводилися за методикою [7; 8] та мають наступну послідовність:

1. Розрахунки вертикального розподілу температури води в Чорному морі на стандартних горизонтах за супутниковими даними [6];

2. Розрахунки вертикального розподілу швидкості звуку в Чорному морі за побудованими рівняннями регресії, за методикою [7; 8].

Для збільшення точності розрахунків вертикального розподілу солоності авторами [8, с. 16] були побудовані рівняння лінійної регресії щодо розрахунку швидкості звуку на глибині 50 метрів. 
Tpemiŭ eman. Розрахунки вертикального розподілу полів солоності в Чорному морі проводилися за розрахованими значеннями температури води та швидкості звуку на основі супутникової інформації. Рівняння ЮНЕСКО для розрахунку швидкості звуку у воді $[10$, с. $11 ; 11$, с. 46] встановлювало залежність між значеннями солоності, температури води, швидкості звуку у воді та гідростатичного тиску. Для визначення солоності $(S)$ та збільшення точності розрахунків рівняння ЮНЕСКО було перетворено у рівняння для розрахунку солоності [8, с. 17].

Дослідження 3 розподілу солоності показали, що в середньому середньоквадратичне відхилення значень у локальному, тобто в конкретно узятій точці та в певний момент часу, вертикальному розподілі солоності в Чорному морі в шарі 0-50 метрів в період весна - осінь, було порядку 0,24\%. Для достатньо високої апроксимації вертикального профілю солоності це відхилення свідчить про не великий розкид значень солоності, тому у розрахунках приймалося, що локальний вертикальний розподіл солоності практично однорідний в цьому шарі. Таким чином, розрахунок локального вертикального розподілу солоності за перетвореним рівнянням проводився для глибини 50 метрів. Розрахована величина солоності на горизонті 50 метрів була постійною величиною для усього шару 0-50 метрів [8].

Локальний розрахунок вертикального розподілу температури та солоності води в Чорному морі за супутниковими та гідроакустичними даними в шарі 0-50 метрів, тобто на декількох станціях, можна легко провести, застосовуючи рівняння, які побудовані за розробленими методиками $[6 ; 7 ; 8]$. Але якщо розраховувати по усій акваторії Чорного моря, то цей процес дуже трудомісткий. Тому, автором цієї статті розроблено Автоматизований Програмний Комплекс розрахунку вертикального розподілу полів температури та солоності води в Чорному морі за супутниковими та гідроакустичними даними (АПК). АПК включає: 864 рівняння експоненціальної та лінійної регресії для розрахунків вертикального розподілу температури води в Чорному морі по місяцях у періоді травень-жовтень; рівняння лінійної регресії для розрахунку поправок на температуру на стандартних горизонтах (10, 20, 25, 50 метрів); інтервали, для визначення розрахунку температури води за рівняннями експоненціальної або лінійної регресії; рівняння лінійної регресії для розрахунків швидкості звуку; рівняння для розрахунків солоності в Чорному морі. 
Таким чином, АПК автоматично визначає де і за якими рівняннями розраховувати вертикальний розподіл температури води i, відповідно, поправки на температуру та солоність води в Чорному морі в шарі 0-50 метрів. Вихідними даними для розрахунків за допомогою АПК $\epsilon$ тільки щоденні супутникові дані температури поверхні моря.

\section{3. Аналіз розподілу розрахованих термохалінних характеристик на основі супутникових та гідроакустичних даних}

Аналіз просторового та вертикального розподілу термохалінних характеристик в діяльному шарі Чорного моря у період травень-жовтень проводився на основі розрахунків за допомогою АПК.

Для дослідження термохалінної структури в діяльному шарі Чорного моря на основі розрахунків АПК були побудовані карти вертикального розподілу температури й солоності води в Чорному морі на зональних і меридіональних розрізах для шести дат, по одній даті для кожного місяця 2018 року в період травень-жовтень. Виявлені особливості у цих розподілах було зіставлено з детальною схемою циркуляції вод Чорного моря (рис. 1), яка наведена у [12].

Вихідними супутниковими даними послужили щоденні відомості по супутниковим вимірів температури поверхні води Чорного моря 3 кроком 4 км за широтою та довготою, вимірювані супутником NASA (Terra MODIS) для 15.05.2018 р.; 21.06 .2018 р.; 08.07.2018 р.; 23.08.2018 p.; 21.09.2018 p.; 15.10.2018 p. [13]. Вибрані для прикладу дати представлені найбільшою кількістю даних супутникових вимірів температури поверхні Чорного моря.

Просторовий розподіл температури поверхні Чорного моря за супутниковими даними зображений на рис. 2. Карти просторового розподілу температури поверхні Чорного моря за супутниковими даними (рис. 2), побудовані за допомогою спеціалізованого програмного забезпечення NASA - SeaDAS [14]. Білі ділянки на рис. 2 характеризують відсутність супутникових даних, наприклад, із-за високої хмарності у момент вимірів. Температурна шкала відповідає оригінальній шкалі для цих вимірів [13].

Координати розподілу зональних та меридіональних океанографічних розрізів для яких проводилися розрахунки вертикального розподілу температури та солоності води за супутниковими та гідроакустичними даними в Чорному морі, представлені в табл. 1. 


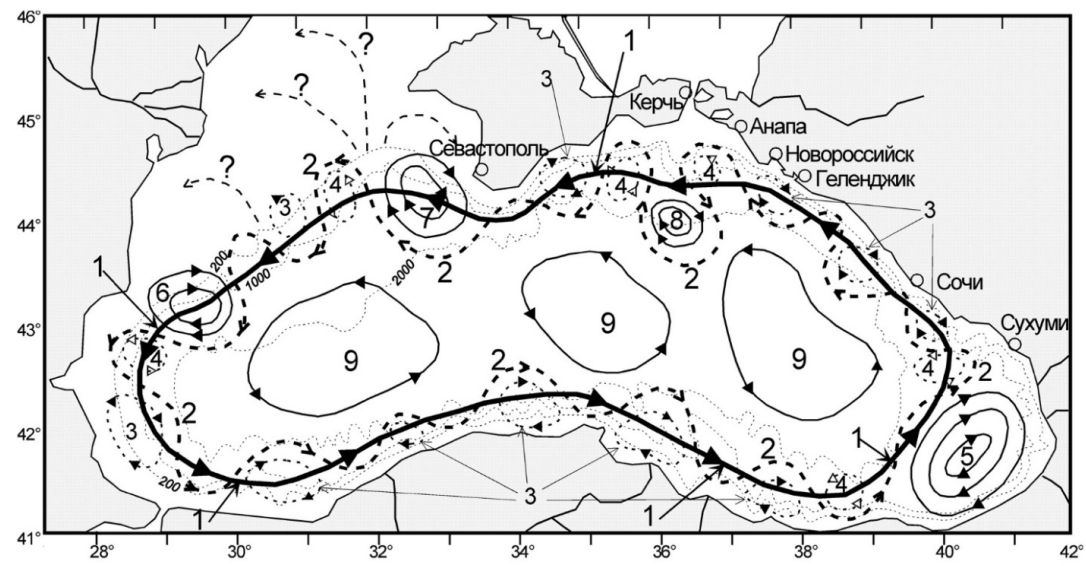

Рис. 1. Схема циркуляції вод Чорного моря, згідно [12, с. 133]:

1 - кільцева ичиклонічна течія (КЦТ) - середнс положення стрижня; 2 -меандри КЦТ; 3 - прибережні антициклонічні вихори (ПАВ); 4- -чиклонічні вихори (ЦВ);

5 - Батумський антициклонічний вихор; 6-Каліакрський ПАВ;

7 - Севастопольський ПАВ; 8 - Керченський ПАВ; 9-квазістаціонарних цчиклонічні кругообіги

Таблиця 1

Координати океанографічних розрізів

для розрахунків вертикального розподілу температури води і солоності в Чорному морі

\begin{tabular}{|c|c|c|}
\hline \multirow{2}{*}{ Дата } & \multicolumn{2}{|c|}{ Океанографічні розрізи } \\
\cline { 2 - 3 } & Зональний, пн.ш. & Меридіональний, сх.д. \\
\hline 15.05 .2018 & $44,00^{\circ}$ & $32,34^{\circ}$ \\
\hline 21.06 .2018 & $43,00^{\circ}$ & $30,40^{\circ}$ \\
\hline 08.07 .2018 & $43,23^{\circ}$ & $30,85^{\circ}$ \\
\hline 23.08 .2018 & $42,60^{\circ}$ & $36,70^{\circ}$ \\
\hline 21.09 .2018 & $43,31^{\circ}$ & $35,77^{\circ}$ \\
\hline 15.10 .2018 & $43,70^{\circ}$ & $33,52^{\circ}$ \\
\hline
\end{tabular}

Результати розрахунків розподілу температури та солоності води у діяльному шарі Чорного моря за допомогою АПК на основі супутни- 


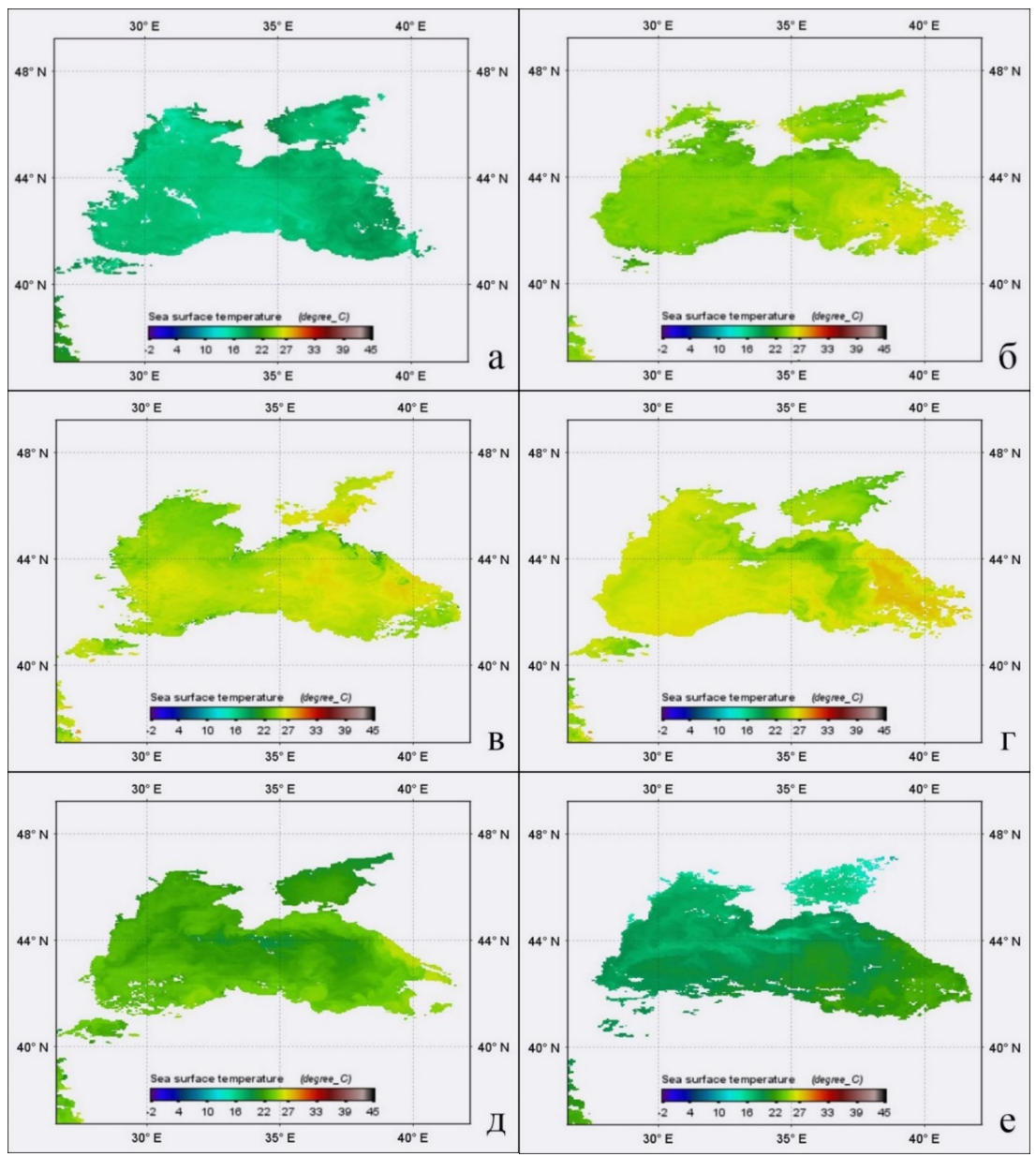

Рис. 2. Просторовий розподіл температури поверхні Чорного моря за супутниковими даними для 15.05.2018 р. (а), 21.06.2018 р. (б), 08.07.2018 р. (в), 23.08.2018 p. (г), 21.09.2018 р. (Д) та 15.10 .2018 р. (е) 


\section{Andrii Sryberko}

кових та гідроакустичних даних на зональних океанографічних розрізах, представлені на рис. 3 .
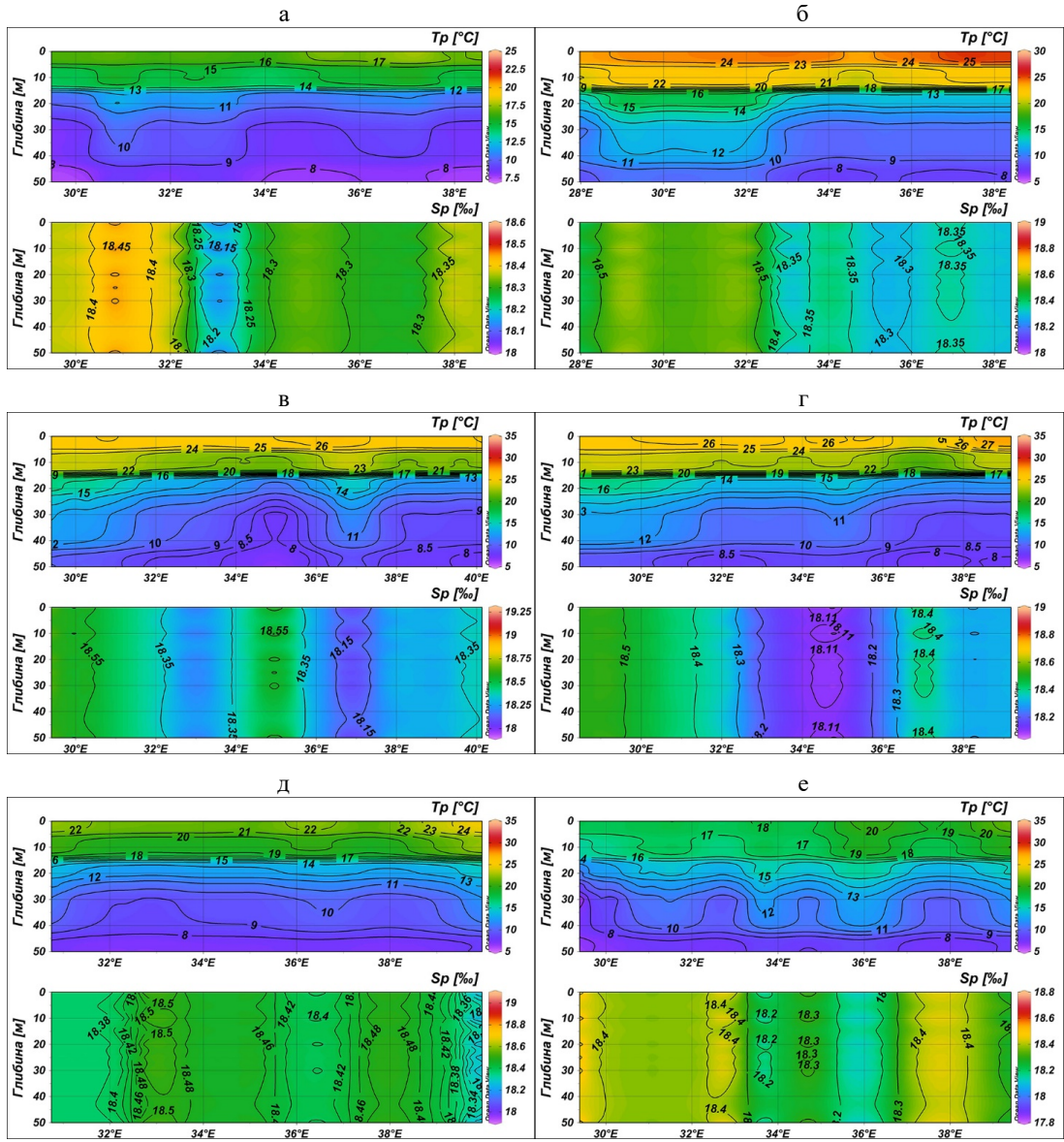

Рис. 3. Розподіл розрахованої температури води (Тр) і солоності

(Sp) на зональних розрізах в Чорному морі на широтах: $44,00^{\circ}$ пн.ШІ. для 15.05.2018 (а); 43,00 $43,23^{\circ}$ пн.Ш. Для 08.07.2018 (в); 42,60 пн.ш. для 23.08.2018 (г); $43,31^{\circ}$ пн.шІ. для 21.09.2018 (д); 43,70 
Проаналізувавши результати розрахунків розподілу термохалінних характеристик на зональних розрізах (рис. 3) виокремимо деякі особливості у цих розподілах.

На рис. 3 (а) можна побачити яскраво виражені 3 куполи в шарі 15 - 50 метрів. Більш прогріті вертикальні шари спостерігаються на меридіанах 3 центрами вертикального перерізу по $31^{\circ}$ сх.д. та $37^{\circ}$ сх.д., які співпадають 3 меандрами ОЧТ у районі материкового схилу та у південно-східному напрямі від Керченського прибережного антициклонічного вихору, відповідно (рис. 1). За критерієм $8^{\circ} \mathrm{C}$, який традиційно $є$ критерієм виділення холодного проміжного шару (ХПШ) $[15$, c. 82], верхня межа ХПШ (3 куполи) спостерігаються починаючи 3 глибини 45 метрів на меридіанах $29,5^{\circ}-30,4^{\circ}$ сх.д., $34^{\circ}-36^{\circ}$ сх.д. та $37,4^{\circ}-38,5^{\circ}$ сх.д.

Значення вертикального розподілу солоності в західній частині Чорного моря склали $18,4 \%$. Мінімальне значення солоності $(S=18,15 \%)$ спостерігалося в Севастопольському прибережному антициклонічному вихорі (рис. 1). На схід від Севастопольського прибережного антициклонічного вихору мінливість значень солоності була в межах 18,3\% - 18,35\%о (рис. 3 (а)).

На рис. 3 (б) більш прогрітий вертикальний шар спостерігається в західній частині Чорного моря, переважно в західному квазістаціонарному циклонічному кругообігу (рис. 1). Починаючи 3 меридіану $33,27^{\circ}$ сх.д. та далі в східному напрямі на глибині 45 метрів спостерігаються 2 куполи верхньої межі ХПШ.

Як видно з рис. 3 (б) більш солоні води $(S \approx 18,5 \%$ ) спостерігаються в західній частині Чорного моря, переважно в західному квазістаціонарному циклонічному кругообігу (рис. 1). Починаючи з меридіану $32,65^{\circ}$ сх.д. та далі на схід солоність в шарі 0-50 метрів знижується та складає близько $18,3 \%$ - 18,35\% .

На рис. 3 (в) спостерігається більш бурхливий розподіл ізотерм у порівнянні $з$ попередніми рис. 3 (а) та 3 (б). Прохолодний вертикальний шар 3 центром вертикального перерізу на меридіані $35^{\circ}$ сх.д. співпадає з серединою центрального квазістаціонарного циклонічного кругообігу (рис. 1) та появою верхньої межі ХПШ на глибині 30 метрів. Відразу після цього шару, далі на захід, спостерігається більш прогрітий шар, який співпадає із західною частиною східного 
квазістаціонарного циклонічного кругообігу (рис. 1). Починаючи 3 меридіану $38^{\circ} \mathrm{cx}$.д., знову починається прохолодний вертикальний шар й тягнеться до меридіану $40^{\circ}$ сх.д., де вже простежується верхня межа ХПШ на глибині 45 метрів, що відповідає зоні ОЧТ в східній частині Чорного моря біля узбережжя Західного Кавказу (район міста Сочі).

Як видно з рис. 3 (в) вертикальний розподіл солоності змінюється iз заходу на схід до центральної частини Чорного моря (до $33^{\circ}$ сх.д.). Далі на схід по паралелі $43,23^{\circ}$ пн.ш. до меридіану $35^{\circ}$ сх.д. відбувається збілышення солоності, де максимальне значення солоності 18,55\% на меридіані $35^{\circ} \mathrm{cx} . д$. співпадає $з$ серединою центрального квазістаціонарного циклонічного кругообігу (рис. 1). Мінімальні значення солоності $\approx 18,05 \%$ спостерігаються на меридіані $37^{\circ}$ сх.д., що співпадає із західною частиною східного квазістаціонарного циклонічного кругообігу (рис. 1).

Більш прогрітий вертикальний шар розташований на заході розpiзу (рис. 3 (г)) стає прохолодніше в східному напрямі по паралелі $42,6^{\circ}$ пн.ш., де починаючи 3 меридіану $36,35^{\circ}$ сх.д. можна спостерігати верхню межу ХПШ на глибині 45 метрів.

Розподіл солоності в розрізі (рис. 3 (г)) змінюється із заходу на схід по паралелі $42,6^{\circ}$ пн.ш до меридіану $34,56^{\circ} \mathrm{cx}$.д., де значення солоності досягають мінімуму $(S \approx 18,11 \%$ ) та співпадає з районом меандру ОЧТ біля центральної частини Анатолійського узбережжя. Далі на схід по паралелі 42,6 пн.ш. значення солоності збільшується до меридіану $37^{\circ}$ сх.д., де значення солоності досягають $18,4 \%$ та співпадає із західною частиною східного квазістаціонарного циклонічного кругообігу (рис. 1). На схід від меридіану $37^{\circ}$ сх.д. солоність знижується на $\approx 0,1 \%$ та складала $\approx 18,3 \%$.

На рис. 3 (д) можна побачити підйом вод в центрі та опусканням на периферії моря формуючи куполоподібний розподіл ізотермічних поверхонь. Подібний розподіл температури води підтверджують автори [15, с. 47]. Верхня межа ХПШ простягається практично уздовж усього розрізу на глибині 45 метрів.

Розподіл солоності являє собою 2 максимуми з солоністю 18,5\% (рис. 3 (д)): перший максимум - на меридіані $33^{\circ}$ сх.д., а другий - на меридіані $38^{\circ}$ сх.д. та зменшенням солоності на периферії моря, що також формує куполоподібний розподіл солоності. Такий розподіл солоності співпадає з думкою авторів [15, с. 57]. 
На рис. 3 (е) видно чітко виражені 3 куполи: перший купол - на меридіані $32,65^{\circ} \mathrm{cx.д.,} \mathrm{який} \mathrm{збігається} 3$ меандром ОЧТ, розташованого на південь від Севастопольського прибережного антициклонічного вихору (рис. 1); другий купол - на меридіані $34,69^{\circ}$ сх.д., який збігається з краєм північної частини центрального квазістаціонарного циклонічного кругообігу (рис. 1); третій купол - на меридіані $37,77^{\circ}$ сх.д., який збігається 3 краєм північної частини східного квазістаціонарного циклонічного кругообігу (рис. 1). Підйом ізотерм в західній частині розрізу збігається з меандром ОЧТ, розташованого на північ від Каліакрського прибережного антициклонічного вихору (рис. 1). Верхня межа ХПШ спостерігається на заході розрізу на глибині 30 метрів 3 подальшим заглибленням до глибини 45 метрів в

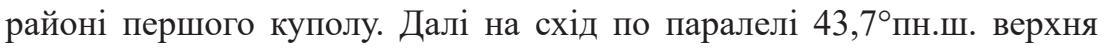
межа ХПШ спостерігається біля другого та третього куполів на глибинах $\approx 50$ метрів та 45 метрів, відповідно.

Вертикальний розподіл солоності (рис. 3 (е)) знаходиться в протифазі з вертикальним розподілом температури води, тобто більш прогріті вертикальні шари відповідають менш солоним вертикальним шарам та навпаки. Розподіл солоності також має куполоподібний характер, куполи яких, співпадають з основними елементами циркуляції Чорного моря, які описані для розподілу температури води (рис. 3 (е)).

Результати розрахунків розподілу температури води та солоності за допомогою АПК на основі супутникових та гідроакустичних даних на меридіональних океанографічних розрізах, представлені на рис. 4.

Рисунки 3 та 4 побудовані за допомогою комп'ютерної програми ODV (Ocean Data View), призначеної для інтерактивного дослідження і графічного відображення океанографічних профілів, траєкторій або часових рядів даних [16].

Проаналізувавши результати розрахунків розподілу термохалінних характеристик на меридіональних розрізах (рис. 4) виокремимо деякі особливості у цих розподілах.

Як видно з рис. 4 (а), розподіл ізотерм практично рівномірний уздовж усього розрізу за винятком прохолоднішого вертикального шару на паралелі $45,15^{\circ}$ пн.ш. в районі західного узбережжя Криму та появою в ньому верхньої межі ХПШ. 
Мінливість значень вертикального розподілу солоності практично рівномірна по усьому розрізу (рис. 4 (а)) та склала $\approx 18,4 \%$.
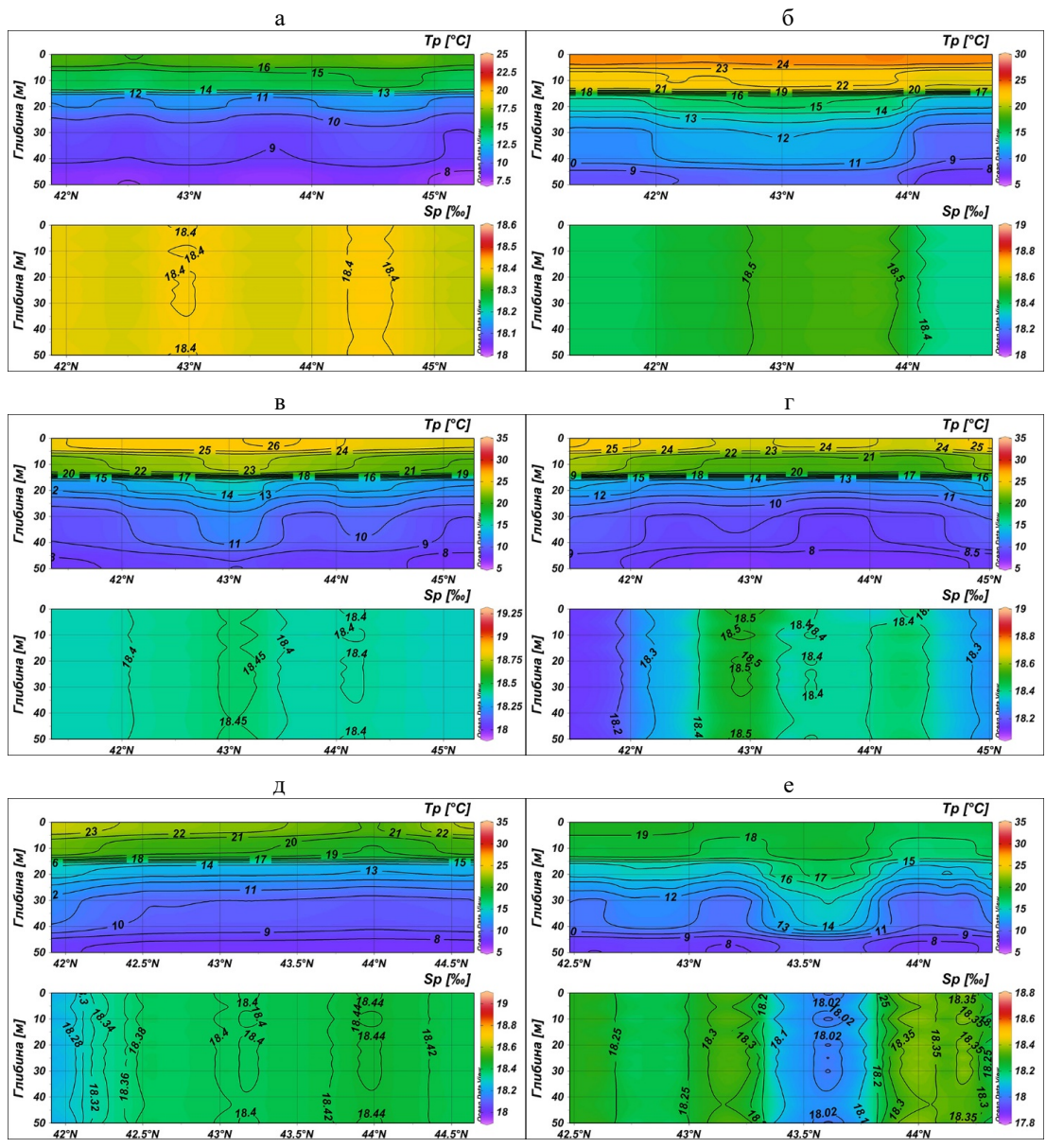

Рис. 4. Розподіл розрахованої температури води (Тр) і солоності

(Sp) на меридіональних розрізах в Чорному морі на довготах:

$32,34^{\circ}$ сх.Д. Для 15.05.2018 (a); 30,40 $30,85^{\circ}$ сх.д. для 08.07.2018 (в); 36,70 $35,77^{\circ}$ сх.д. Для 21.09.2018 (д); 33,52 ${ }^{\circ}$ сх.Д. для 15.10.2018 (е) 
Чітко виражений, прогрітий вертикальний шар (рис. 4 (б)) спостерігається в зоні ОЧТ та в західному квазістаціонарному циклонічному кругообігу (рис. 1). Починаючи 3 паралелі $44^{\circ}$ пн.ш. та далі в північному напрямі по меридіану $30,4^{\circ}$ сх.д. західної частині Чорного моря, розташований прохолодний вертикальний шар з появою верхньої межі ХПШ на глибині 45 метрів. На південь від паралелі $42^{\circ}$ пн.ш., також спостерігається менш прогрітий шар на горизонтах 20-40 метрів.

Розподіл солоності $(S \approx 18,5 \%$ ) приблизно однорідний по усьому розрізу до паралелі $44^{\circ}$ пн.ш. (рис. 4 (б)). Далі, в північному напрямі від паралелі $44^{\circ}$ пн.ш., спостерігається зниження солоності на $0,1 \%$, значення солоності дорівнювали $\approx 18,4 \%$.

На рис. 4 (в) більш прогрітий вертикальний шар спостерігається на паралелі $43^{\circ}$ пн.ш., який розташований в західному квазістаціонарному циклонічному кругообігу (рис. 1). Верхня межа ХПШ спостерігається в південному напрямі по меридіану $30,85^{\circ}$ сх.д., починаючи 3 паралелі $41,81^{\circ}$ пн.ш. в зоні ОЧТ поблизу західної частини Анатолійського узбережжя та в північному напрямі по меридіану 30,85 сх.д., починаючи 3 паралелі 44,65 пн.ш. в районі материкового схилу.

Вертикальний розподіл солоності по усьому розрізу (рис. 4 (в)) практично однорідний та складає 18,4\%о 3 невеликим збільшенням на 0,05\% на паралелі $43^{\circ}$ пн.ш., що знаходиться у західному квазістаціонарному циклонічному кругообігу (рис. 1).

Мінливість значень вертикального розподілу температури води супроводжується невеликим підняттям ізотерм в центральній (мористій) частині та опусканням на периферії східної частини моря (рис. 4 (г)). Верхня межа ХПШ спостерігається уздовж більшої частини розрізу на глибині 45 метрів, починаючи 3 паралелі 42,15 пн.ш. до 44,8 пн.ш.

Вертикальний розподіл солоності в розрізі (рис. 4 (г)) має максимум $18,5 \%$ на паралелі $42,94^{\circ}$ пн.ш., яка проходить між центральним та східним квазістаціонарними циклонічними кругообігами (рис. 1). Мінімальні значення солоності 18,2\%о притаманні до зони ОЧТ в районі гирла р. Єшиль-Ирмак центральної частини Анатолійського узбережжя.

На рис. 4 (д) спостерігається невеликий купол ізотерм на паралелі $44^{\circ}$ пн.ш., який співпадає 3 меандром ОЧТ, розташованого на захід від Керченського прибережного антициклонічного вихору (рис. 1). Опускання ізотерм відбувається в районі прибережного антициклоніч- 
ного вихору центральної частини Анатолійського узбережжя (рис. 1). Верхня межа ХПШ простягається практично уздовж усього розрізу на глибині 47 метрів.

Розподіл солоності має максимум 18,44\% на паралелі $44^{\circ}$ пн.ш 3 подальшим повільним зменшенням значень солоності в північному напрямі уздовж меридіану $35,7^{\circ} \mathrm{cx}$.д. та мінімумом значень солоності 18,22\% на периферії моря, в районі гирла р. Кизил-Ірмак центральної частини Анатолійського узбережжя (рис. 4 (д)).

На рис. 4 (е) видно 3 куполи ізотермічних поверхонь 3 центрами вертикального перерізу: перший купол - на паралелі $42,56^{\circ}$ пн.ш., який співпадає з меандром ОЧТ, розташованого на північ від прибережного антициклонічного вихору центральної частини Анатолійського узбережжя (рис. 1); другий купол - на паралелі $43,15^{\circ}$ пн.ш., який розташований по середині між західним та центральним квазістаціонарними циклонічними кругообігами (рис. 1); третій купол - на паралелі $44,06^{\circ}$ пн.ш., який збігається 3 меандром ОЧТ, розташованого на південний схід від Севастопольського прибережного антициклонічного вихору в районі південного берега Криму (рис. 1). Також на рисунку видно чітко виражений більш прогрітий вертикальний шар з центром вертикального перерізу на паралелі 43,56н.ш., який знаходиться по середині між меандром ОЧТ, розташованого у південно-східному напрямі від Севастопольського прибережного антициклонічного вихору в районі південного берега Криму та центральним квазістаціонарним циклонічним кругообігом (рис. 1). Верхня межа ХПШ простежується під усіма 3-ма куполами: під першим куполом - на глибині $\approx$ 50 метрів; під другим й третім куполами - на глибині 45 метрів.

Вертикальний розподіл солоності має характер протифази по відношенню до вертикального розподілу температури води (рис. 4 (е)). Чітко виражені максимальні значення солоності (близько 18,35\%о) під другим та третім куполами ізотерм (рис. 4 (е)). Яскраво виражений вертикальний шар 3 мінімальними значеннями солоності $(\mathrm{S} \approx 18 \%$ ) відповідає більш прогрітому вертикальному шару температури води 3 центром вертикального перерізу на паралелі 43,56п.ш. (рис. 4 (е)).

Максимум вертикального градієнту розрахованих значень температури води на стандартних горизонтах в Чорному морі спостерігався в шарі 10 - 20 метрів та не перевищував $1,17^{\circ} \mathrm{C}$ м-1 (табл. 2). 
Таблиця 2

Максимуми вертикального градіснту розрахованих значень температури води на стандартних горизонтах в Чорному морі

\begin{tabular}{|c|c|c|}
\hline Дата & Шар, $\mathbf{~}$ & Градіснт, ${ }^{\circ} \mathbf{C}$ м-1 \\
\hline 15.05 .2018 & $10-20$ & 0,62 \\
\hline 21.06 .2018 & $10-20$ & 1,03 \\
\hline 08.07 .2018 & $10-20$ & 1,15 \\
\hline 23.08 .2018 & $10-20$ & 1,17 \\
\hline 21.09 .2018 & $10-20$ & 1,00 \\
\hline 15.10 .2018 & $10-20$ & 0,80 \\
\hline
\end{tabular}

Вертикальний градієнт значень солоності в цій статті не розглядається, так як зазначалося вище, що локальний 50-ти метровий шар вертикального розподілу солоності вважався однорідним.

Проаналізувавши в цілому розрахунки просторового розподілу термохалінних характеристик в діяльному шарі Чорного моря на стандартних горизонтах $(0,10,20,25,30,50$ метрів) за допомогою АПК на основі супутникових (рис. 2) та гідроакустичних даних можна виокремити деякі особливості у цих розподілах.

Просторовий розподіл температури води поверхневого шару в Чорному морі в період травень-жовтень 2018 року відповідає найбільш характерним рисам, які притаманні для Чорного моря, а саме ростом температури води у напрямку від північного заходу на південний схід.

Звернемо увагу на локальні мінімуми температури води в просторовому розподілі:

1) у травні (15.05.2018) - уздовж центральної частини Анатолійського узбережжя, що співпадає з дослідженнями, які описані у роботі $[15$, с. 50]. Цей мінімум викликаний стійким апвелінгом;

2) у червні (21.06.2018) - уздовж центральної частини Анатолійського узбережжя, Керченсько-Таманського шельфу та району західної частини Криму;

3) у липні (08.07.2018) - уздовж західної частини Керченсько-Таманського шельфу та південно-східного узбережжя Криму, а також західного узбережжя Криму;

4) у серпні (23.08.2018) - уздовж південно-східного узбережжя Криму з виходом в мористу акваторію східної частини Чорного моря; 
5) у вересні (21.09.2018) - уздовж паралелі $44^{\circ}$ пн.ш. від меридіану $31,8^{\circ}$ сх.д до $35,69^{\circ}$ сх.д, який розташований на півночі центральної частини Чорного моря;

6) у жовтні (15.10.2018) - уздовж південно-східного узбережжя Криму та районів Керченсько-Таманського шельфу й західної частини Криму.

Просторовий розподіл солоності в період травень-жовтень 2018 року має характерні риси, які притаманні для Чорного моря. Максимальні значення солоності припадають на райони західного та східного квазістаціонарних циклонічних кругообігів (рис. 1) та в районі протоки Босфор. Мінімальні значення солоності спостерігаються уздовж центральної та східної частин Анатолійського узбережжя; південно-східного узбережжя Криму та Керченсько-Таманського шельфу під впливом більш розпрісненних азовоморських вод та в районі західного узбережжя Криму.

На закінчення відзначимо, що розроблені методики $[6 ; 7 ; 8]$ та Автоматизований Програмний Комплекс (АПК) дозволяють відновлювати просторовий розподіл температури й солоності води в морському середовищі за супутниковими та гідроакустичними даними в шарі 0-50 метрів в період весна - осінь для проведення детального аналізу стану термохалінної структури.

\section{4. Висновки}

В результаті проведеного аналізу термохалінної структури морського середовища на основі побудованих карт вертикального розподілу температури й солоності води в діяльному шарі глибоководної частини Чорного моря на зональних і меридіональних розрізах для шести дат, по одній даті для кожного місяця 2018 року в період травень-жовтень за результатами розрахунків АПК були здобуті підтвердження стану термохалінного режиму, притаманного до Чорного моря у теплий період року.

В цілому, результати розрахунків вертикального розподілу термохалінних характеристик у глибоководній частині Чорного моря за супутниковими та гідроакустичними даними за розробленими методиками показали можливість та доцільність їх застосування в шарі 0-50 метрів в період травень-жовтень для проведення детального аналізу стану термохалінної структури. 
Принципи побудови АПК для розрахунків вертикального та просторового розподілу температури та солоності води у перспективі можливо втілити щодо створення «Системи аналізу та моніторингу полів термохалінних характеристик на основі дистанційних методів вимірів», що дозволить оцінювати динаміку процесів в морському середовищі, особливості просторово-часової мінливості термохалінних характеристик та вплив їх змін на гідробіологічні, гідрохімічні, гідрофізичні процеси та екосистему моря в цілому.

Розроблені методики та принципи побудови АПК для розрахунків вертикального та просторового розподілу температури та солоності води в морському середовищі за супутниковими та гідроакустичними даними, які випробувані на прикладі Чорного моря, можуть бути застосовані для аналізу і моніторингу інших акваторій Світового океану 3 урахуванням їх гідрологічних умов.

\section{Список літератури:}

1. Ильин Ю. П., Репетин Л. Н., Белокопытов В. Н., Горячкин Ю. Н., Дьяков Н. Н., Кубряков А. А., Станичный С. В. (2012) Гидрометеорологические условия морей Украины. Том 2: Черное море. Севастополь : МО УкрНИГМИ, 2015. 421 с.

2. Андрианова О. Р., Скипа М. И., Сриберко А. В., Степанова Ю. В. Оценка возможности расчета вертикального распределения температуры воды в Черном море по спутниковым данным. Вісник Одеського національного університету. Серія : Географічні та геологічні науки. Том 20. Вип. 4. С. 9-21.

Андрианова О. Р., Батырев А. А., Скипа М. И., Сриберко А. В. Подспутниковая заверка и интерпретация данных космической съемки морской поверхности. Космічна наука і технологія. 2004. Том 10. № 4. С. 92-95.

3. Oguz, T., Tugrul, S., Kideys, A. E., Ediger, V., \& Kubilay, N. Physical and biogeochemical characteristics of the Black Sea (28, S). The sea. 2005. Vol. 14. Chapter 33. Pp. 1333-1371.

4. Пустовойтенко В. В., Запевалов А. С. Оперативная океанография: современное состояние, перспективы и проблемы спутниковой альтиметрии. Севастополь : ЭКОСИ-Гидрофизика, 2012. 218 с.

5. Sryberko A. Calculation of the vertical distribution of water temperature in the Black Sea by satellite data. Geographia Technica. 2019. Vol. 14. Issure 2. Pp. 97-111. https://doi.org/10.21163/GT_2019.142.09

6. Андріанова О. Р., Сриберко А. В. Методика розрахунків розподілу швидкості звуку за температурою води наприкладі Чорного моря. Український гідрометеорологічний журнал. 2019. № 24. C. 83-91. https://doi.org/10.31481/ uhmj.24.2019.08

7. Андріанова О. Р., Сриберко А. В. Методика розрахунків вертикального розподілу полів термохалінних характеристик для глибоководної акваторії 
Чорного моря за даними дистанційних вимірів. Вісник Одеського національного університету. Серія : Географічні та геологічні науки. 2019. Том 24. Вип. 2. С. 11-25.

8. Андрианова О. Р., Батырев А. А., Белевич Р. Р., Скипа М. И. Черное море как полигон для отработки дистанционных методов контроля: монография. Киев : Наукова думка, 2018. 156 с.

9. Ярошенко А. А. Вычисление скорости звука в морской воде. От Колладона и Штурма до наших дней. Водний транспорт. 2012. Вип. 3. С. 8-12.

10. Fofonoff N. P., Millard Jr. R. C Algorithms for computation of fundamental properties of seawater. UNESCO Technical Papers in Marine Sciences. Paris, France, UNESCO. 1983. Vol. 44. 53 p.

11. Кривошея В. Г. Натурные исследования пространственно-временной изменчивости течений прибрежно-шельфовой зоны черноморского побережья России. Динамические прочессы береговой зоны моря. Москва : Научный мир, 2003. C. 131-151.

12. NASA's OceanColor Web (2020) National Aeronautics and Space Administration, OceanColor Web. Retrieved from: https://oceancolor.gsfc.nasa. gov/13/ (accessed December 2020).

13. NASA's SeaDAS (2020) National Aeronautics and Space Administration, SeaDAS. Retrieved from: https://seadas.gsfc.nasa.gov/about/ (accessed December 2020).

14. Иванов В. А., Белокопытов В. Н. Океанография Черного моря. Севастополь: НАН Украины, Морской гидрофизический институт, 2011. 212 с.

15. Schlitzer R. (2020) Ocean Data View. Retrieved from https://odv.awi.de (accessed December 2020).

\section{References:}

1. Ilyin, Yu. P., Repetin, L. N., Belokopytov, V. N., Goryachkin, Yu. N., Dyakov, N. N., Cubryakov,A.A., \& Stanichnyi, S. V.(2012) Gidrometeorologicheskie usloviya morey Ukrainy. Tom 2: Chernoe more [Hydrometeorological conditions of the seas of Ukraine. Volume 2: The Black Sea]. Sevastopol: UkrNIGMI, 421 p. (in Russian)

2. Andrianova, O. R., Skipa, M. I., Sryberko, A. V. \& Stepanova, Y. V. (2015) Otsenka vozmozhnosti rascheta vertikal'nogo raspredeleniya temperatury vody $\mathrm{v}$ Chernom more po sputnikovym dannym [Estimation of ability of vertical temperature distribution's calculation for the Black sea's water by satellite data]. Herald ONU. Geography and Geology, vol. 20, no. 4, pp. 9-21.

3. Andrianova, O. R., Batyrev, A. A., Skipa, M. I., \& Sriberko, A. V. (2004) Podsputnikovaya zaverka i interpretatsiya dannykh kosmicheskoy s'emki morskoy poverkhnosti [Undersatellite authentication and interpretation of the data of space surveys of a sea surface]. Kosmichna Nauka i Tekhnologiya, vol. 10, no. 4, pp. 92-95.

4. Oguz, T., Tugrul, S., Kideys, A. E., Ediger, V., \& Kubilay, N. (2005) Physical and biogeochemical characteristics of the Black Sea $(28$, S). The sea, vol. 14, ch. 33, pp. 1333-1371. 
5. Pustovoytenko, V. V. \& Zapevalov, A. S. (2012) Operativnaya okeanografiya: sovremennoe sostoyanie, perspektivy i problemy sputnikovoy al'timetrii [Operational Oceanography: Satellite altimetry - the current status, prospects and problems]. Sevastopol: Ecos-Hydrophysics, 218 p. (in Russian)

6. Sryberko, A. (2019) Calculation of the vertical distribution of water temperature in the Black Sea by satellite data. Geographia Technica, vol. 14, issure 2, pp. 97-111. https://doi.org/10.21163/GT_2019.142.09

7. Andrianova, O. R., \& Sryberko, A. V. (2019) Metodyka rozrakhunkiv rozpodilu shvydkosti zvuku za temperaturoiu vody na prykladi Chornoho moria [Methods for calculating the speed of sound distribution by water temperature: case study for the Black Sea]. Ukrainian hydrometeorological journal, vol. 24, pp. 83-91. https://doi.org/10.31481/uhmj.24.2019.08

8. Andrianova, O. R., \& Sryberko, A. V. (2019) Metodyka rozrakhunkiv vertykalnoho rozpodilu poliv termokhalinnykh kharakterystyk dlia hlybokovodnoi akvatorii Chornoho moria za danymy dystantsiinykh vymiriv [The method for calculations the vertical distribution of the fields of thermohaline characteristics for the Black Sea deep-water area by remote measurements data]. Herald ONU. Series: Geography and Geology, vol. 24, no. 2, pp. 11-25.

9. Andrianova, O. R., Batyrev, O. A., Belevich, R. R., \& Skipa, M. I. (2018) Chernoe more kak poligon dlya otrabotki distantsionnykh metodov kontrolya: monografiya [Black sea - as a polygon for development of remote control methods]. Kyiv: Naukova Dumka, 168 p. (in Russian)

10. Yaroshenko, A. A. (2012) Vychislenie skorosti zvuka v morskoy vode. Ot Kolladona i Shturma do nashikh dney [The calculation of sound velocity is in the sea water. From Colladon and Sturm to our days]. Water transport, vol. 3, pp. 8-12.

11. Fofonoff, N. P. \& Millard, Jr. R. C (1983) Algorithms for computation of fundamental properties of seawater. UNESCO Technical Papers in Marine Sciences. Paris, France, UNESCO, vol. 44, 53 p.

12. Krivosheya, V. G. (2003) Naturnye issledovaniya prostranstvenno-vremennoy izmenchivosti techeniy pribrezhno-shel'fovoy zony chernomorskogo poberezh'ya Rossii [Field study of spatial-temporal changeability of currents on Russian part of Black Sea coastal - shelf zone]. Dinamicheskie protsessy beregovoy zony morya [Dynamical Processes In the Sea Nearshore Zone]. Moscow: Scientific World, pp. 131-151.

13. NASA's OceanColor Web (2020) National Aeronautics and Space Administration, OceanColor Web. Retrieved from: https://oceancolor.gsfc.nasa.gov/13/ (accessed December 2020).

14. NASA's SeaDAS (2020) National Aeronautics and Space Administration, SeaDAS. Retrieved from: https://seadas.gsfc.nasa.gov/about/ (accessed December 2020).

15. Ivanov, V. A., \& Belokopytov, V. N. (2011) Okeanografiya Chernogo morya [Oceanography of the Black Sea]. Sevastopol: NAS of Ukraine, Marine Hydrophysical Institute, 212 p. (in Russian)

16. Schlitzer R. (2020) Ocean Data View. Retrieved from: https://odv.awi.de (accessed December 2020). 